\title{
MANGROVE FOREST SPECIES COMPOSITION AND DENSITY IN BALOK RIVER, PAHANG, MALAYSIA
}

\author{
M.Z. Rozainah and M.R. Mohamad \\ Institute of Biological Sciences \\ University Malaya, 50603 Kuala Lumpur, Malaysia \\ Email: rozainah@um.edu.my
}

\begin{abstract}
Sixteen mangrove species from 10 families, including four associate species, were recorded in 4 study plots along the riverbanks of Balok river, Kuantan and Pahang. Rhizophora apiculata and Xylocarpus granatum appeared in all plots. $R$. apiculata shows the highest density ( 819 per ha) followed by $R$. mucronata (775 per ha). Highest species diversity was recorded in the order of plots located on downstream to the river mouth, based on the Shannon-Weiner Diversity Index.
\end{abstract}

Key words: Mangrove, flora, ecology, regeneration, dominance, diversity, Pahang.

\section{INTRODUCTION}

The tsunami that struck the Indian Ocean region on 26 December 2004, resulting in the loss of more than 250,000 lives and countless property, has revived much interest in the importance of mangroves. Coastlines fringed by mangroves were significantly less damaged than those where mangroves were absent or had been removed. This coastal green-belt can protect the land from strong waves and wind, by absorbing and reducing the amplitude (height) and energy of waves. Furthermore, it maintains the shape and structure of the coastline, preventing erosion and protecting human settlements from being washed into the sea. Mangrove species have been lost on both coasts of Peninsular Malaysia due to erosion and land clearing for agricultural ponds, resorts and plantation. The gradual loss of Malaysian mangroves should be addressed before it is too late.

Malaysia has approximately 645,852 ha of mangroves which is the third largest in the Asia Pacific region (Azahar and Nik Mohd Shah 2003). Peninsular Malaysia has one of the most diverse mangrove assemblages in the world, with at least
38 exclusive and 57 non-exclusive and associate mangrove species (Lokman and Sulong 2001). Tomlinson (1986) has clearly defined the classification of mangrove vegetation into three classes: exclusive, non-exclusive and associates; based on each species' adaptation.

Botanical and ecological studies like forest composition and population structure are vital for evaluating tree productivity in mangrove forests. Various studies on mangrove forest have been carried out over the past years. For example, timber production by Putz and Chan (1986), litter and root production by Ong et al (2004), biomass study by Norhayati and Latiff (2001) and demographic study by Gong and Ong (1995). The objective of this paper was to reveal the mangrove trees composition in Balok river and to discuss the general ecological impacts inflicted on the ecosystem.

\section{MATERIALS AND METHODS}

Balok river in the state of Pahang runs south from Sg Karang passing Balok village, a small fishing village, before flowing into the South China Sea on the East coast of Peninsular Malaysia. The 
Gebeng Industrial Park which is located upstream has been in existence since 1990; consisting of mainly electronics, petrochemicals, and rubber and palm oil factories and chemical pollution is evident in parts of the river. The Balok mangrove forest covers an area of 121 ha, and the length of Balok river is $11 \mathrm{~km}$. The study area in Balok river is located at N $3^{\circ} 56^{\prime} 15.5^{\prime \prime}$ and E $103^{\circ} 22^{\prime} 25.5^{\prime \prime}$, about $15 \mathrm{~km}$ north of the major port city of Kuantan.

Two plots (A and B) are located downstream, close to the river mouth, while other two plots (C and D) are located upstream, closer to the industrial area. Each plot's size was $20 \mathrm{~m} \times 20 \mathrm{~m}$. Every existing species that occurred within the boundary were identified, tagged and scored for its density, height, basal area and diameter at breast height $(\mathrm{dbh})$ readings. The quantitative readings were used to calculate Importance Value Index (IVI) and Shannon-Weiner Diversity Index (H') (Mac Arthur 1969). According to a classification by Watson (1928), the common mangrove species like Rhizophora mucronata, $R$. apiculata and Bruguiera parviflora take about 14-16 years to reach circumference of $25 \mathrm{~cm}$. Following the same method, the authors have classified 3 life stages:

1. adult, with a circumference more than $25 \mathrm{~cm}$

2. juvenile, with a circumference of up to $25 \mathrm{~cm}$

3. seedling, where the individual recently germinated and bears young leaves - usually less than $0.5 \mathrm{~m}$ high.

\section{RESULTS}

There were 16 species including four associate species, from 10 families, recorded within the 4 study plots (Table 1). In addition, a survey along the river towards the river mouth revealed another 6 species. The list of these species is shown in Table 2. Rhizophora apiculata and Xylocarpus granatum were present in all plots (Table 3 ). $R$. apiculata showed the highest density ( 819 trees per ha) followed closely by $R$. mucronata (775 trees per ha). The mean height of the adults of $R$. mucronata was $10.12 \pm 1.56 \mathrm{~m}$ and $R$. apiculata at $13.37 \pm 4.08 \mathrm{~m}$. The highest tree in the present study was recorded for $R$. apiculata at $23 \mathrm{~m}$. The mean dbh for adults of $R$. mucronata and $R$. apiculata was $12.12 \pm 3.34 \mathrm{~cm}$ and $14.40 \pm 5.94$ $\mathrm{cm}$ respectively. Plots $\mathrm{A}$ and $\mathrm{B}$ contained 11 species and that the most important species was $R$. mucronata. The Importance Value Index for each species is shown in Table 1. This value takes into account the density of each species in each plot, basal area and frequency. The Shannon-Weiner Diversity Index $(\mathrm{H})$ was highest in Plot $\mathrm{A}$ with the value of 2.72 , followed by Plots B, D and C respectively (Table 3 ).

Plots $\mathrm{C}$ and $\mathrm{D}$ at upstream side had 7 species and in both plots, $R$. apiculata was the most important species, while an associate species; Acrostichum aureum, becomes the second important species. Although A. aureum can be seen almost everywhere on the forest floor in these plots, this species was very small compared to $R$. apiculata; therefore, the basal area data was relatively small.

Plot B showed the highest likelihood of good regeneration for mangrove exclusive species, gathered from the very high number of juveniles (115) and a few seedlings (2) compared to adults (30) (Table 4). Plots (C and D) at upstream had no seedlings at all, and the number of juveniles was less than adults. Depending on how long-lived these species are, there is a fear that this small number of juveniles may not be able to replace the older generations which are unable to produce new offsprings. 
Table 1. Importance Value Index of mangrove exclusive and associates species in 4 study plots in Balok River, Pahang.

\begin{tabular}{|c|c|c|c|c|c|}
\hline Family & Species & Plot A & Plot B & Plot C & Plot D \\
\hline Rhizophoraceae & Rhizophora mucronata Lamk & 27.66 & 33.94 & & \\
\hline Rhizophoraceae & Rhizophora apiculata $\mathrm{Bl}$. & 15.84 & 4.49 & 38.77 & 30.86 \\
\hline Euphorbiaceae & Excoecaria agallocha $\mathrm{L}$. & 12.54 & 2.68 & & 11.33 \\
\hline Rhizophoraceac & Bruguiera cylindrica L. & 12.69 & & 1.94 & 2.39 \\
\hline Meliaceae & Xylocarpus granatum Koenig & 16.42 & 18.82 & 15.22 & 9.09 \\
\hline Avicenniaceae & Avicennia officinalis $L$. & 5.36 & 0.66 & & \\
\hline Combretaceae & Lumnitzera littorea (Jack) Voight & 3.70 & 1.95 & & \\
\hline Rhizophoraceae & Bruguiera parviflora (Roxb.) Ding Hou & 2.27 & 11.57 & & \\
\hline Sonneratiaceac & Sonneratia caseolaris (L.) Engl. & 1.46 & & & \\
\hline Combretaceae & Lumnitzera racemosa Willd. & & 2.84 & & \\
\hline Avicenniaceae & Avicennia alba $\mathrm{Bl}$. & & 11.11 & & \\
\hline Sonneratiaceae & Sonneratia alba Sm. & & & 2.72 & \\
\hline Pteridaceae & Acrostichum aureum L.* & 0.90 & 10.44 & 30.19 & 26.18 \\
\hline Leguminosae & Derris heterophylla(Willd)* & 1.17 & 1.5 & & \\
\hline Malvaceae & Hibiscus tiliaceus L.* & & & 4.39 & 5.86 \\
\hline Rutaceae & Merope angulata (Willd.) Swingle* & & & 6.77 & 14.29 \\
\hline
\end{tabular}

"Mangrove associates

Table 2. Other mangrove trees found in Balok river.

\begin{tabular}{ll}
\hline Species & Family \\
\hline Bruguiera gymnorrhiza (L.) Lamk & Rhizophoraceae \\
Ceriops tagal (Perr.) C.B. Robinson & Rhizophoraceae \\
Flagellaria indica L. & Flagellariaceae \\
Nypa fruticans Wurmb & Arecaceae \\
Oncosperma tigillarium (Jack) Ridl. & Arecaceae \\
Phoenix paludosa Roxb. & Arecaceae \\
\hline
\end{tabular}

Table 3. Number of individuals, density per ha and Shannon Weiner Diversity Index of mangrove exclusive species in all four 0.04 ha study plots.

\begin{tabular}{lccccc}
\hline Species & Plot A & Plot B & Plot C & Plot D & Density (ha-1) \\
\hline Rhizophora mucronata & 38 & 86 & & & 775 \\
Rhizophora apiculata & 17 & 8 & 86 & 20 & 819 \\
Excoecaria agallocha & 17 & 3 & & 12 & 200 \\
Bruguiera cylindrica & 16 & & 21 & 2 & 244 \\
Xylocarpus granatum & 14 & 21 & 8 & 4 & 294 \\
Avicennia officinalis & 6 & 1 & & 44 \\
Lumnitzera littorea & 5 & 4 & & 56 \\
Bruguiera parviflora & 4 & 8 & & 75 \\
Sonneratia caseolaris & 1 & & & 6 \\
Lumnitzera racemosa & & 4 & & \\
Avicennia alba & & 10 & & & \\
Sonneratia alba & 2.72 & 2.03 & 1.12 & 1.58 & \\
Shannon-Weiner Diversity Index H' & & & & \\
\hline
\end{tabular}


Table 4. The total number of adults, juveniles and seedlings of all mangrove exclusive species in 4 study plots.

\begin{tabular}{lcccc}
\hline Stage & Plot A & Plot B & Plot C & Plot D \\
\hline Seedling & 15 & 2 & 0 & 0 \\
Juvenile & 63 & 115 & 26 & 6 \\
Adult & 55 & 30 & 62 & 33 \\
\hline
\end{tabular}

\section{DISCUSSION}

Norhayati et al. (2004) studied mangrove species composition in 5 sites in Santi and Pulai FR (Johore), Ayer Hangat and Kisap FR (Langkawi) and Matang FR (Perak). They recorded between $3-9$ species in each site ranging from 0.06 ha to 1 ha size plot and $R$. mucronata and $R$. apiculata being the most common. In the present study, a total of 12 mangrove exclusive species were recorded at Balok river within a total of 0.16 ha area, which was only $32 \%$ of the total mangrove exclusive as listed by Lokman and Sulong (2001). The common species $R$. apiculata and $R$. mucronata had been found in the south and west of Peninsular Malaysia by Norhayati et al. (2004).

An extensive study of species composition and biomass in Kisap FR, Langkawi by Norhayati and Latiff (2001), recorded 9 mangrove species and also revealed $R$. apiculata as the most dominant species. However, the density of $R$. apiculata in Balok river is far greater; 819 trees per ha compared to Kisap FR (557 trees per ha). Balok river also recorded the density of $X$. granatum as was 294 trees per ha but Kisap FR recorded less than half i.e. 90 trees per ha. In a comparison, Matang FR has a record of $2190 R$. apiculata trees per ha in its 23 year-old stand (Gong and Ong 1995), but then Matang FR contains pure stand of Rhizophora spp only.

The present data show that Balok river can be considered as an excellent in terms of its species composition and density, considering that Balok river is a short river and close to an industrial park. According to Curtis and Macintosh (1951), an Important Value Index that is more than 10 can be considered as dominant for a tropical forest species; hence the mangrove forest in Balok river may be further classified as Rhizophora zone. A study by Chai (1982) revealed that a combination of $R$. mucronata and X. granatum in Plots $\mathrm{A}$ and $\mathrm{B}$ constituted a 'subtype' which suggests that Balok river is a secondary mangrove forest. The existence of $X$. granatum was caused by the sandy forest floor brought up from Balok beach. Avicennia spp are typical of seaward species and therefore only recorded in seaward plots (A and B) but not in backward plots (C and D).

The mass occurrence of $A$. aureum, $M$. angulata and $H$. tiliaceus in plot D is consistent with the lack of canopy in this site. These species only require a little amount of light to start with, and are soon able to change the environment to suit their needs. It risks soon becoming a bare, open and degraded area. Gradually, this site will change its soil structure and subsequently its vegetation types towards terrestrial ecosystem. More mangrove species will be replaced by associate and terrestrial species, together with changes of hydrology and this might lead to the end of mangrove zone in this area. Wilcox (1995) stated that some of the changes that take place following changes in hydrology are the increase of associate species that can tolerate disturbance, like $A$. aureum and $H$. tiliaceus, and the decrement of species diversity index, exactly like has been observed in these plots. Eradicaton of A. aureum to make way for young mangrove establishment is not easy. They can be both laborious and very costly (Chan 1989). If the area is not backed by younger individuals (Table 4), regeneration process will not be able to take place. This area could therefore be in a vulnerable state, easily falling prey to 
unsustainable development project such as aquaculture ponds. Therefore, the present species composition data is important as part of management of natural resources and monitoring in any changes of ecosystem quality.

The reductions of mangrove forests have been observed in most states in the Peninsular of Malaysia as cited by Latiff (2004). Steps have been taken by Forestry Department to conserve some of these forests as forest reserve. In addition to that, a sound management system is introduced. Matang Mangrove Forest in Perak is one of the best managed mangrove forests for wood and charcoal productions (Haron 1981). In 2000, the price of charcoal produced from Matang Mangrove was RM600 per ton, as compared to RM413 per ton in 1991; an increase of $45 \%$ over a period of 10 years (Azahar and Nik Mohd Shah 2003). This comes with a hefty price Matang Forest has decreased its biodiversity value by being a silviculture plantation of Rhizophora spp. for wood production. Thus, the challenge of preserving and managing any type of remaining forest still persists. That is to develop a forest-friendly sustainable ecosystem in order to provide food and jobs while also preserving the environment.

\section{ACKNOWLEGMENT}

The authors would like to thank University of Malaya and BASF-Petronas Kuantan for financial support, and Mr Nagappan, Mr Ponniah, Mr Rosli, Miss Siti Fatimah and Miss Aaina for field assistance. Our appreciation to Mr L. Renshaw for editing the manuscript.

\section{REFERENCES}

Azahar Muda and Nik Mohd Shah Nik Mustafa 2003. A Working Plan for the Matang Mangrove Forest Reserve, Perak: the third 10-year period (2000-2009) of the second rotation. State Forestry Department of Perak Darul Ridzuan. 319 pp.
Chai, P.K. 1982. Ecological Studies of Mangrove Forest in Sarawak. Ph.D. Thesis, University of Malaya, Kuala Lumpur.

Chan, H.T. 1989. A Note on the Eradication of Acrostichum aureum ferns in the Matang Mangroves, Perak, Peninsular Malaysia. Journal of Tropical Forest Science 2(2):171173.

Curtis, J. T. and R.P. Macintosh. 1951. An Upland Forest Continuum in the Prairie Forest Border Region of Winsconsin. Ecology 32:476-496.

Gong, W.K. and J.E. Ong. 1995. The use of demographic studies in mangrove silviculture. Hydrobiologia 295:255-261.

Haron, A.H. 1981. A Working Plan for the Second 30-Year Rotation of the Matang Mangrove Forest Reserve Perak. The First 10 Year Period 1980 - 1989. State Forestry Department of Perak. 115 pp.

Latiff, A. 2004. Conservation of Mangrove Biodiversity in Peninsular Malaysia. National Conference on Sustainable Management of Matang Mangroves - 100 Years and Beyond. 5 - 8 October 2004, Ipoh, Perak, Malaysia.

Lokman, M.H.and I. Sulong. 2001. Mangroves of Terengganu. Mangrove Research Unit (MARU) and Forestry Department Peninsular Malaysia. $135 \mathrm{pp}$.

MacArthur, R.H. 1969. Patterns of Species Diversity. Biol. Rev. 40:510-533.

Norhayati A. and A. Latiff. 2001. Biomass and species composition of a mangrove forest in Pulau Langkawi, Malaysia. Malays. Appl. Biol. 30(1\&2):75-80.

Norhayati, A., M.S. Nizam, W.A. Juliana, M.N. Shukor, A.F. Fera Fizani, Hafizah Seman, H. 
Sariah, J. Jamaliah, A.K. Intan Nordira and A. Latiff. 2004. Comparison of mangrove tree species composition at selected locations in peninsular Malaysia. National Conference on Sustainable Management of Matang Mangroves - 100 Years and Beyond. 5-8 October 2004, Ipoh, Perak, Malaysia. 11 pp.

Ong, J. E., W.K. Gong and C.H. Wong. 2004. Allometry and partitioning of a 20 year-old stand of Rhizophora apiculata mangrove forest. Forest Ecology and Management. 188:395-408.

Putz, F.E. and H.T. Chan. 1986. Tree Growth Dynamics. Forest Ecology and Management. 178:211-230.
Tomlinson, P.B. 1986. The Botany of Mangroves. Harvard University. Cambridge University Press. Cambridge, U.K. 433 pp.

Watson, J.G. 1928. Mangrove Forests of the Malay Peninsula. Malayan Forest Records No 6. Federated Malay States, Kuala Lumpur. 275 pp.

Wilcox, D.A. 1995. Wetland and Aquatic Macrophytes as Indicators of Anthropogenic Hydrologic Disturbance. Natural Areas Journal 15:240-248. 